\title{
Educational Studies through Distance and Contact Teaching
}

\author{
Tuulikki Viitala \\ Shool of Vocational Teacher Education
}

\begin{abstract}
The pedagogical studies of vocational teachers include 10 credits of studies in education. Half of our students complete them in connection with teachers' pedagogical studies. The training has been bought from the University, and it has consisted of distance education. Some of the students have felt that studying education according to university requirements has been hard for them. They would like a more practical approach to educational studies. Our students also come from a large area of northern Finland. Therefore distance education opportunities are important for them. Tutoring has an important role in this implementation. To respond to these challenges, we have designed a more practical implementation of the educational studies. Students have only two face-to face days. The educational studies piloted in the autumn term 2012. The pilot succeeded very well. Students liked to study and they had learned much of different areas of education.
\end{abstract}

\section{Introduction}

Studies in education provide the basis for a vocational teacher's pedagogical studies. Therefore, understanding the basic concepts of education is essential for the progress of later studies. Some of our students have felt that the university-provided educational studies are too theoretical, so they have wanted a more practical approach to the studies and an opportunity to do more together.

Underlying the pilot implementation was the construction of collaborative knowledge [12]. By making use of the learning environment, the participants can simultaneously create messages, comment on each other's messages and organize the ideas and thought presented based on the messages. In this way, the ideas and knowledge developed can be improved on all the time. In practice, however, the study process does not proceed in a linear fashion, as it is an interactive whole that focuses on collaboration, networking and overlap in development. Dissemination, distribution and combination of knowledge and competence is essential to the process $[2,15]$.
The term "knowledge building" is used commonly in the literature. We used the perspective that focuses on the production and continual improvement of ideas of value to a community [12]. A knowledge building community is similar to research community where members engage in progressive inquiry working at the edge of their understanding. Two key ideas are of particular importance: Ideas are improvable through progressive discourse, and members share collectively responsibility for improving not only their but others' understanding [4].

\section{Collaborative online learning}

The concept of collaborative learning has commonly come up in the everyday work of educational institutions. Collaborative learning is being supported by means of various technologies, especially online environments which have been designed to promote and support collaborative knowledge construction. Research on computersupported collaborative learning has proved that the use of online environments can support reflection on one's own experiences and cognitive activities together with other learners, thereby promoting profound understanding of things [3]. Collaborative learning is not easy, however, and to support the work it is important to identify some of the prerequisites of collaborative learning [11].

Research results indicate that collaborative learning presupposes, among other things, in-depth discussions, the learners' equal participation in the work and a joint basis on which to work. According to Vuopala, there has been less research on the learners' experiences of collaborative learning and its prerequisites. According to her, understanding the students' experiences is, however, essential for the design, implementation, tutoring and assessment of collaborative learning situations. In her research Vuopala has studied factors promoting and hindering collaborative learning in an online course based on the experiences of university students [17].

According to the research results obtained by Vuopala, necessary conditions for success in collaborative learning include the group members' commitment to their joint goal, equal participation in collaborative work and the sense of belonging to a 
group between the group members. Successful collaborative learning calls for negotiated interaction in which the learners justify their views and negotiate on them. The research results by Vuopala also show similarly to previous studies that the learners need to have a sufficient joint understanding of the words and concepts used, and the language needs to be common to the learners [17]. A somewhat surprising result in this study is the relatively slight significance of the tutor's activities during the course in promoting learning. The subjects also did not feel that issues related to the individual were significant for the success of collaborative learning. Meanwhile factors connected with the group and the group's activities were important from the viewpoint of successful collaborative learning. There was a special emphasis on issues related to the quality of the interaction between the students, such as reciprocity of the discussions and presentation of reasons.

According to Vuopala, attention should thus be given in the design of collaborative learning situations to group formation. Issues connected with course arrangements are also essential factors promoting collaborative learning. Assignment in particular shall take place in such a way that successful solution calls for interaction and collaborative work. According to the study, a situation of successful collaborative learning was manifested in argumentative discussion, and the analysis of the discussion shows that discussion in these situations was commentating and interactive by nature. The discussions were also more active in situations of successful collaborative learning than in unsuccessful ones. Messages not connected with theme were relatively more numerous in unsuccessful rather than successful situations of collaborative learning, with the exception of the first working period. The quantity of discussion that is not relevant to the theme at the beginning of a course is indicative of the importance of informal discussion for group formation and launching the group's activities [17].

According to Antola, an online teacher must be able to plan and guide the entire online learning process [2]. Special attention must be given to launching the group's activities, the peer support given by the group and the tutor's online attendance throughout the course. According to her, the development of the quality of e-learning requires teachers specialized in online learning. The significance of an individual learning environment will become greater in e-learning. Collaborative learning is also promoted by virtual networks which are formed through collaboration between several actors. The study conducted by Antola highlighted the role of the tutor to a much higher degree than that by Vuopala [17].

\section{Vocational Education}

As our institution offers its students a set of studies in vocational pedagogy, the viewpoint of vocational education is also important in their studies. Although it is about basic studies in education, the studies can be targeted at vocational education and its practices. This is most appropriate, as our students have a solid working life experience and it is important for them to be able to make use of their experiences in their studies $[6,7]$.

Vocational education as a science has been defined as a subfield of education that is interested in human growth for a vocation and related problematics. Ruohotie [9, 10], Laakkonen [8] has defined vocational education as follows: "Vocational education is an organized educational activity by means of which adolescents and adults can accomplish learning that proceeds in a goal-oriented way, with the objective of the acquisition and development of competencies needed in a vocation and of creating the conditions for independent vocational activity and continuous development in a vocation." Research areas in vocational education have included, among others, the learning of a vocation, vocational education and its development, professional growth as a lifelong Process and knowledge management [5], [14].

\section{Tutoring}

The online environment is defined as an open learning environment. It is pedagogically and technically appropriate environment for the student designed to be available on the data networks. Based on the model suggested by Anderson et al. [1], Wang [16]has further specified and outlined four dimensions of the tutor/tutoring, dividing the responsibilities and roles in tutoring into pedagogical, social, managerial and technical tutoring. These forms of tutoring are all with in this pilot.

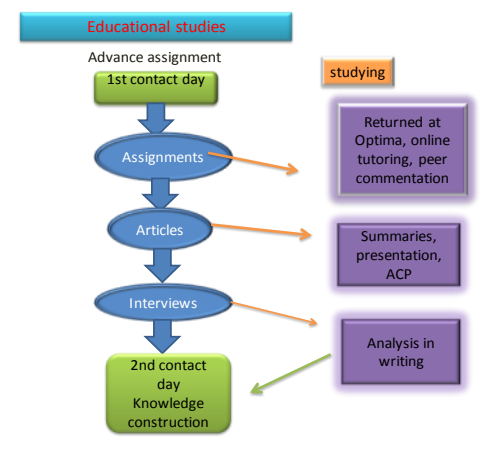

Figure 1. The model for educational studies in the University of Applied Sciences 
In the studying model contact teaching is only provided at the start and end of the studies. Studying happens mostly on the Optima environment. Tutoring of the students occupies a central role in the model. Thirty students are accepted to the studying group.

Phare 1. The studies start with the advance assignments. The purpose of these assignments is to orient the students for the studies, to make them familiar with the central concepts of education. This is how they get prepared for the first contact teaching day. The assignments are not returned to the tutor teacher before the first contact teaching day, as the assignments completed by the students function as an orientation in the first day's group and joint discussion tasks.

Phase 2. The first contact teaching day. In this meeting, they build together a knowledge base for studies in education. The main teaching methods are the teaching discussions and group assignments led by the tutor teacher. As the students have called for a practical approach to educational studies, an effort is made in the discussions to tie the educational terminology with everyday experience as well as possible. On the first contact day the students also get to know each other, and group building starts.

Phase 3. The assignment are the same, however. The students are given assignments in which the meaning is to get familiar with educational terminology and to gain a deeper understanding of the concepts. The assignments are done in small groups and publish them on the Optima platform. All the members of each small group see the work of other groups. The groups comment on each other's work in writing on the Optima platform. The tutor is also available throughout the work in a special tutoring forum, for instance.

Phase 4. In the assignment for this phase, the students familiarize themselves with educational research and present studies to each other. This takes place through social media, such as AC. It is essential to discuss the studies. The assignment can also be completed in pairs. The tutor teacher is also present in the study presentations.

Phase 5.Inthis phase students plan and conduct interviews. The small groups plan and interview those in practice educational tasks, such as vocational teachers and other people working in the field of education. The interviews are analyzed in groups and presented to the other small groups via $\mathrm{AC}$, for instance. The tutor teachers are closely involved in implementation.

Phase 6. The members for a joint closing seminar. The tutor teacher summarizes what has been learnt and discusses with the students. The idea is to construct knowledge together. Students last four and half months.

1. How did the students feel about the way the students in education were organized.
2. How dis the students feel about working in groups?

3. How has the students felt about tutoring and feedback in the course.

4. Did the viewpoint of vocational training came up in the studies?

5. Did the students think that the studies were practically oriented?

6. Did the students achieve the goals they had set for their studies in education?

7. How did the students' knowledge of education and its various areas develop during the studies as assessed by the students themselves?

Research sample

17 students from the School of Vocational Teacher Education participated in the educational studies pilot group. The students represented different vocational fields.

\section{Collection of research data}

An electronic pre-survey questionnaire was constructed in the learning environment (Optima), and all the students responded to it. The same inquiry was also made at the end of the studies. The students replied to the written final inquiry when they were having their second face-to-face day at the end of the studies. Both inquiries used the Likert scale, with the pre and post-surveys using a 5-point scale and the final inquiry a 4-point scale.

\section{Research results}

As a whole, the students feedback indicate that the study module pilot in educational studies was highly successful. Most of the students were very satisfied with the way the studies were organized (mean 3.83). The students estimated that the ratio between distance and face-to-face teaching was good (3.38). They also had positive feelings about Adobe Connect remote session. All the students considered that it was at least successful (3.57). Most concern was caused by technical problems, and not quite all of the students were able to attend the session.

The integrative face-to-face session at the start of the studies was considered somewhat more successful (3.81) than the first face-to-face day for orientation to the studies. Both these face-to-face occasions were, however, thought to be either successful or very successful.

The students were also satisfied with the progress of group work. Collaboration on all three assignments had proceeded excellently, with the means ranging between 3.56 and 3.83. Towards the end, the cooperation that had been good to start with improved even more.

The students were quite satisfied with tutoring (3.60), and they were also satisfied with reception of 
feedback (3.62). They had received feedback from both the tutor and their fellow students.

Without an exception, all the students considered that the studies were practically oriented. The students had also been able to put their own experiences into good use (3.63). They had also felt that professionalism was highlighted well in the studies (3.75). There was also a high degree of satisfaction with the contents of the studies (3.56).

The students were asked at both the start and end of the studies what they tought of their own knowledge of education and its development during the studies (knowledge of education, vocational education, educational psychology, sociology of education, educational research and the field of work of vocational teachers. The students estimated that the knowledge had increased in every respect. Their knowledge had increased most in educational sociology and psychology. Their general knowledge of education had also increased. Meanwhile, their knowledge of the history and research of education had not quite increased as much as that of the other areas of education. The means in the initial measurement ranged between 2.00 and 3.41, and in the final measurement between 3.41 and 4.24. The differences between the initial and final measurement vere statistically highly significant in the various areas of education.

\section{Discussion}

Educational studies are very important in our pedagogical studies. They provide the basis for a vocational teacher's pedagogical studies. They provide the basis for a vocational teachers' pedagogical studies. Therefore, understanding the basic concepts of education is essential for the progress of later studies. Some of our studies have felt that the university-provided educational studies are too theoretical, so they have wanted a more practical approach to the studies and an opportunity to do together. Students take part in our training from very large sparsely populated area all the way to the northernmost Lapland.

According to the student feedback, the educational studies pilot was highly successful. An effort was made to minimize conceptualization typical of university studies. The students considered without an exception that the studies had been practically oriented, allowing the students to make use of their own experiences. The students had also benefited a lot from the contents of the studies.

I think this pilot also succeeded very well in combining distance and face-to-face teaching as well as group work. Although there were only two days of face-to-face sessions, working groups between these sessions inspired a community spirit, supporting and guiding the students. The work in the groups had proceeded without any problems. It would thus appear that this mode of study enables joint construction of knowledge, one of the essential elements is students teaching each other. The task of coordinating the studies and the main responsibility for giving feedback lies with the teacher/tutor in charge of the study module.

\section{References}

[1]T. Anderson, L. Rourke, D. Carrison, R and W Archer, (2001). Assessing teaching in a computer conferencing context. JALN - Journal of Asynchronous Learning Networks, (5)2.

[2] K. Antola, (2011). Vuorovaikutuksen kehittäminen verkko-oppimisessa: kokemuksia ja havaintoja ammattikorkeakouluopetuksesta. Hämeen ammattikorkeakoulu. Ammatillinen opettajakorkeakoulu. Opinnäyte.

[3]J. A. Beairsto, (1996). Professional growth and development: What is it and how do we know if it's working? Teoksessa P. Ruohotie \& P. P. Grimmett (Eds.) Professional growth and development: Direction, delivery and dilemmas. Vancouver: Career Education Center. 91111

[4]A. Game and A. Metcalfe, (2009). Dialogue and team teaching. Higher Education Research \& Development, 28 (1), 45-57.

[5]P. Ihanainen, (2010), Ammatillinenverk kopedagogiikka. Haaga-Helian julkaisusarja, Puheenvuoroja 3/2010.Multiprint Vantaa.

[6]K. Korpelainen \& P. Nokelainen \& P. Ruohotie (2009). Ammatillisen huippuosaamisen mallintaminen. Ammattikasvatuksen aikakauskirja 11(1), 33-47/ISBN 1456-7989/OKKA-säätiö.

[7] K. Korpelainen, (2005). Kasvun pelivara. Innovatiivisuus, motivaatio ja jaksaminen markkinointiviestintäyrityksissä. Tampereen yliopisto. Acta Universitas Tamperensis 1902.

[8] A. Laakkonen, (2004). Hoitohenkilöstön ammatillinen kasvu hoitokulttuurissa. Tampereen yliopisto Acta Unversitatis Tamperensis 996.

[9] P. Ruohotie, (2005) Oppiminen ja ammatillinen kasvu. Sanoma Pro.

[10]P. Ruohotie, (2000). Oppiminen ja ammatillinen kasvu. Juva: WSOY.

[11] P. Sahlberg \& A. Leppilampi, A., (1994). Yksinään vai yhteisvoimin - yhdessäoppimisen mahdollisuuksia etsimässä. Vantaa: Helsingin yliopisto, Vantaan täydennyskoulutuslaitos.

[12] M. Scardamalia \& C. Bereiter, (2003). Knowledge building. In Guthrie, J.W. (Ed.) Encyclopedia of Education (2nd ed.). New York: Macmillan Reference USA. 
[13] A.B. Smith, C.D. Jones, and E.F. Roberts, (2009) "Article Title", Journal, Publisher, Location, Date, pp. 110.

[14] M. Tasala, (2012). Osaamisen tunnistaminen ja tunnustaminen tulevat syrjäyttämään nykyisenlaisen tutkintojärjestelmän. Ammattikasvatuksen aikakauskirja 14(2012) 90-95.OKKA säätiö.

[15] Valtion tiede-ja teknologianeuvosto, (2003). Osaaminen, innovaatiot ja kansainvälistyminen.

[16] Q. Wang, (2008) Student-facilöitators'roles in moderating online discussions. British Journal of Educational Technology, 39 (5), 859-874.

[17] E. Vuopala, (2010). Yhteisöllistä oppimista edistävät ja vaikeuttavat tekijät verkkokurssilla Teoksessa: Tuovi, T: Interaktiivinen tekniikka koulutuksessa 2010- konferenssin tutkijatapaamisen artikkelit. 